\title{
Land-Use Barriers and Incentives to the Use of Solar Energy
}

Paul Spivak
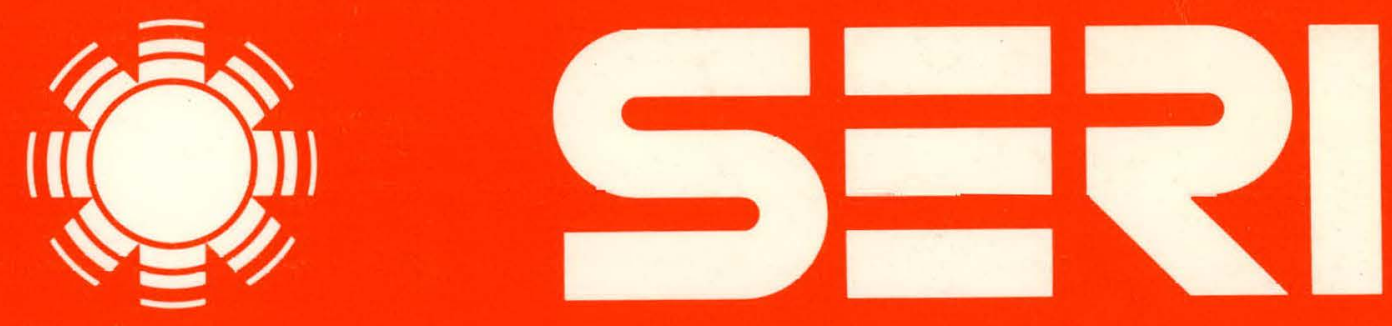

Solar Energy Research Institute

A Division of Midwest Research Institute

1536 Cole Boulevard

Golden, Colorado 80401

Operated for the

U.S. Department of Energy under Contract No. EG-77-C-01-4042

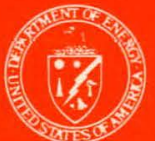




\section{DISCLAIMER}

This report was prepared as an account of work sponsored by an agency of the United States Government. Neither the United States Government nor any agency Thereof, nor any of their employees, makes any warranty, express or implied, or assumes any legal liability or responsibility for the accuracy, completeness, or usefulness of any information, apparatus, product, or process disclosed, or represents that its use would not infringe privately owned rights. Reference herein to any specific commercial product, process, or service by trade name, trademark, manufacturer, or otherwise does not necessarily constitute or imply its endorsement, recommendation, or favoring by the United States Government or any agency thereof. The views and opinions of authors expressed herein do not necessarily state or reflect those of the United States Government or any agency thereof. 


\section{DISCLAIMER}

Portions of this document may be illegible in electronic image products. Images are produced from the best available original document. 
Printed in the United States of America Available from:

National Technical Information Service

U.S. Department of Commerce

5285 Port Royal Road

Springfield, VA 22161

Price: $\$ 5.25$

Microfiche $\$ 3.00$

Printed Copy \$

\section{NOTICE}

This report was prepared as an account of work sponsored by the United States Government. Neither the United States nor the United States Department of Energy, nor any of their employees, nor any of their contractors, subcontractors, or their cmployccs, makes any warranty, express or implied, or assumes any legal iiability or responsibility for the accuracy, completeness or usefulness of any information, apparatus, product or process disclosed, or represents that its use would not infringe privately owned rights. 


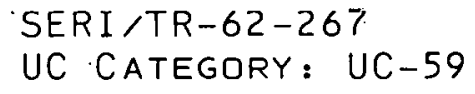

PAUL SPIVAK

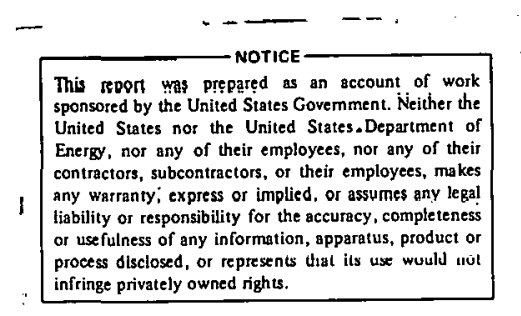

-

\section{Solar Energy Research institute}

15'36 Cole Boulevard

Golden, Colorado 80401

A Division of Midwest Research Institute

Prepared for the IIS Tiepariment of Energy

Contract No. EG $\cdot 77 \cdot \mathrm{C} \cdot 01 \cdot 4042$ 
THIS PAGE

\section{WAS INTENTIONALLY LEFT BLANK}




\section{FOREWORD}

This paper on land-use barriers and incentives to the use of solar energy was prepared by the Solar Energy Research Institute (SERI) to fulfill, in part, SERI's solar information dissemination function. This paper is part of the Market Development Branch Law Program, which in turn is part of the overall program of the Technology Commercialization Division.

This is the seventh of eight 1978 Summer Law Intern Papers sponsored by the SERI Law Program. The other seven address (1) the impact of the antitrust laws on the commercialization of solar heating and cooling, (2) licensing arrangements and the development of the solar energy industry, (3) problems in the administration of state solar legislation, (4) legal and institutional implications of providing financial incentives to encourage the development and implementation of biomass energy technologies, (5) legal considerations in the development and implementation of biomass energy technologies, (6) state approaches to solar energy incentives, and (7) utility rates and service policies as potential barriers to the market penetration of decentralized solar technologies. These eight studies are meant to raise and discuss the primary legal issues that are, or will be, generated by the commercialization of solar technologies.

The author of this paper, Paul Spivak, was a student at the University of Colorado Law School while he was participating in the 1978 Summer Law Intern program. He is now a third-year student at the University of Colorado Law School. The Law Program would like to acknowledge the editorial assistance provided this paper by Seymour Joseph, a law clerk to the Law Program during the summer of 1979.

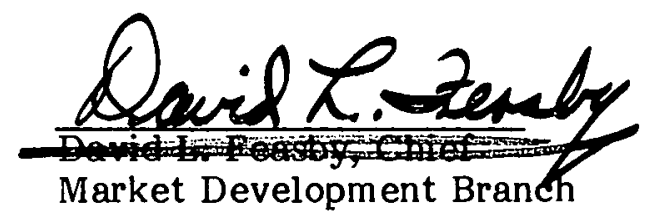

Approved for:

SOLAR ENERGY RESEARCH INSTITUTE

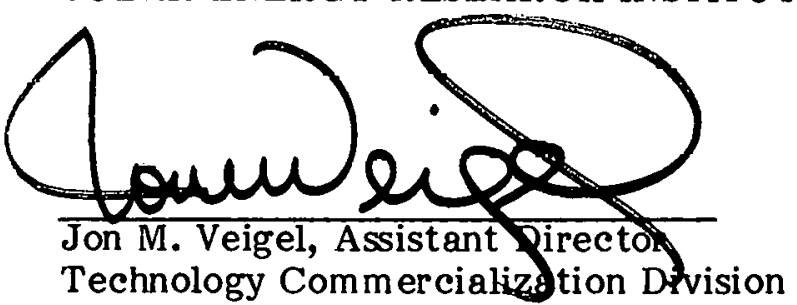


THIS PAGE

\section{WAS INTENTIONALLY LEFT BLANK}




\section{SUMMARY}

The effect of land-use regulations on the commercialization of solar energy technologies has not been ignored in the legal literature. There has been, however, a need to compile, organize, and analyze the large and rapidly expanding mass of material already written on the subject. This paper analyzes such land-use issues and focuses specifically on a discussion of on-site uses of active and passive solar heating and cooling.

The first area discussed involves land-use regulations which prohibit the installation of solar collectors. Such regulations include both public regulations (zoning laws) and private regulations (restrictive covenants). After analyzing the ways in which such regulations can hinder solar energy utilization, the discussion turns to the ways in which such barriers can be removed.

The widely discussed issue of secure access to sunlight, also known as solar rights, comprises the bulk of the report. The many different proposed methods of ensuring solar access are compared to an "ideal" solar right. The ideal right put foward (1) provides secure access before installation of the collector, (2) minimizes the hardship to neighbors of the owner of the solar-equipped building; (3) allows for flexibility, (4) minimizes the procedural burdens imposed on the person seeking the solar right, and (5) minimizes the administrative and enforcement costs of the system of rights.

The solar access problem is divided into two parts: access in new developments and access in existing neighborhoods. Solar acess in new developments can be provided fairly easily, if desired, by a combination of land-use tools which allow for the flexible siting of buildings and restrictive covenants to control vegetation. The problem of access in existing neighborhoods does not lend itself to easy solutions. The main solutions analyzed-privately negotiated easements, zoning laws, and allocated "sun rights" - have drawbacks. This paper identifies the disadvantages of each approach, and discusses ways to minimize those difficulties.

The final area addressed is the variety of ways in which land-use regulations can be structured to provide an incentive to install solar equipment. Various degrees of incentive are evaluated, ranging from forcing consideration of solar energy use in development plans, to mandatory installation of solar technologies. 
THIS PAGE

\section{WAS INTENTIONALLY LEFT BLANK}




\section{TABLE OF CONTENTS}

$\underline{\text { Page }}$

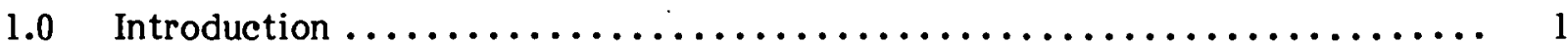

$2.0 \quad$ Land-Use Restriction Barriers $\ldots \ldots \ldots \ldots \ldots \ldots \ldots \ldots \ldots \ldots \ldots \ldots \ldots \ldots$

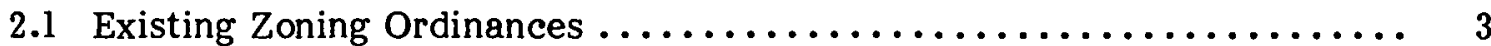

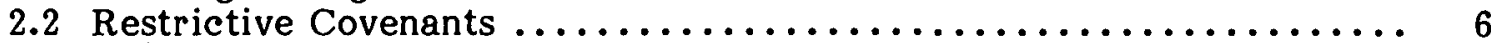

2.3 Nuisance Law $\ldots \ldots \ldots \ldots \ldots \ldots \ldots \ldots \ldots \ldots \ldots \ldots \ldots \ldots \ldots \ldots \ldots$

3.0 Characteristics of a Desirable Solar Right $\ldots \ldots \ldots \ldots \ldots \ldots \ldots \ldots \ldots \ldots \ldots$

$4.0 \quad$ Solar Access $\ldots \ldots \ldots \ldots \ldots \ldots \ldots \ldots \ldots \ldots \ldots \ldots \ldots \ldots \ldots \ldots \ldots \ldots \ldots$

4.1 Common Law Mechanisms to Secure Solar Access ............. 11

4.2 Contractual Solar Access............................ 12

4.3 Preliminary Considerations to Legislated Solar Access .......... 14

5.0 Constitutional Considerations $\ldots \ldots \ldots \ldots \ldots \ldots \ldots \ldots \ldots \ldots \ldots \ldots \ldots$

6.0 Comprehensive Plans $\ldots \ldots \ldots \ldots \ldots \ldots \ldots \ldots \ldots \ldots \ldots \ldots \ldots \ldots \ldots \ldots$

7.0 Zoning for Solar Access in Existing Neighborhoods . . . . . . . . . . . 19

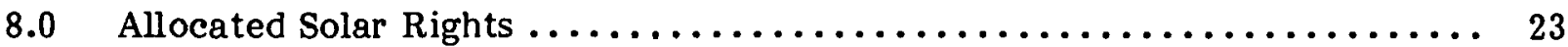

$9.0 \quad$ Transferable Development Rights $\ldots \ldots \ldots \ldots \ldots \ldots \ldots \ldots \ldots \ldots \ldots \ldots \ldots$

10.0 Solar Access in New Developments $\ldots \ldots \ldots \ldots \ldots \ldots \ldots \ldots \ldots \ldots \ldots \ldots \ldots$

11.0 Mandatory Use of Solar Energy $\ldots \ldots \ldots \ldots \ldots \ldots \ldots \ldots \ldots \ldots \ldots \ldots \ldots$

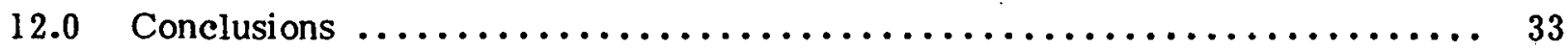

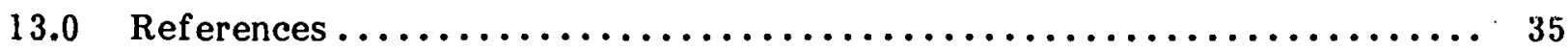




\section{SECTION 1.0}

\section{INTRODUCTION}

For a technology to be efficiently utilized, a society is often required to alter old institutions and laws or to create entirely new ones. Land-use regulations and the property rights they affect are influenced by the demands of widely used technologies. For example, the U.S. dependence on large centralized power generators has resulted in laws allowing utilities to obtain rights-of-way (easements) over privately owned land for running power lines. However, for the most part, centralized power generation requires few land-use regulations.

Unlike centralized power generation, the use of solar energy technologies places constraints on land use. To fully utilize solar energy, existing land-use obstacles to the installation of solar collectors must first be reduced. Next, owners of solar collectors need assurance that they will have access to sunlight. In addition, methods of incorporating solar energy usage in land-use plans for future development should be considered. This paper evaluates methods of altering land-use regulations to accommodate the widespread usage of solar energy.

The primary technologies discussed are the use of sunlight for heating and cooling buildings and heating water. Solar energy systems utilizing sunlight are divided into active and passive technologies. Active systems circulate air or water through collectors, while passive systems utilize portions of the actual structure for collecting solar energy, and usually have no moving parts. Both need sunlight, and therefore, throughout this paper active and passive systems are discussed together unless otherwise indicated.

Other solar technologies, such as the use of photovoltaics and wind energy conversion systems to produce electricity, are also discussed. These technologies, especially photovoltaics, often. raise the same issues as the technologies mentioned previously. Unless qualified, the term "solar collector" in this paper means a device or structure that uses any of the preceding solar technologies.

This paper examines land-use issues raised by the use of on-site solar energy systems. On-site implies collectors located on or near the building that uses the energy produced by the collector. On-site solar systems are only large enough to meet or supplement the needs of that one building. Although land-use issues usually do not differ among individual solar technologies, the issues vary depending on the location of the collector. As a result, many of the land-use issues are discussed in terms of their impact on existing neighborhoods, rather than on new developments. 


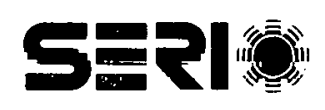




\section{SECTION 2.0}

\section{LAND-USE RESTRICTION BARRIERS}

\subsection{EXISTING ZONING ORDINANCES}

The primary land-use problem associated with solar energy technologies involves securing access to sunlight (and/or wind). However, zoning regulations, restrictive covenants, and other legal impediments to placing solar collectors on a parcel of land are the threshold problem in the analysis. For example, if a zoning regulation promoting neighborhood aesthetics prohibits the installation of solar equipment, ensuring access to that solar energy would not be necessary. There are many different types of zoning regulations that may hinder the use of onsite solar technologies. Though probably initially drafted without considering their impact on the solar energy industry, such regulations were universally enacted to promote the public health, safety, morals, or general welfare [1]. Therefore, where these ordinances may unintentionally obstruct the use of solar energy, it is necessary to examine whether removal of such zoning barriers would produce a social harm greater than any social benefit that would occur from the use of solar energy.

One common type of zoning ordinance that could be an obstacle in certain situations is the height restriction ordinance [2]. The problem would arise when an owner wishes to place a solar hot water heater or an active solar heating and cooling system on the roof top of a building already built to the applicable height limit. Since the angle of the roof may not be suitable for the efficient collection of sunlight, it could be necessary to place the collectors at a steeper angle, causing them to exceed the height limit. Whether the collectors are of the type of rooftop protrusions that are usually excepted in height restriction ordinances would be doubtful.

A typical list of "special exceptions" [3] to height restrictions is: " . . spires, belf ries, cupolas, antennas, water tanks, ventilators, chimneys, or other appurtenances usually required to be placed above the roof level and not intended for human occupancy" [4]. A solar collector would seem to be one type of appurtenance excepted under such an ordinance. However, solar collectors are different from the exceptions normally listed because they of ten occupy more area. For example, the city of Boulder, Colo. has a similar list of appurtenances that are treated as special exceptions to the normal height limits. However, the Boulder Planning Department is not allowed to consider such appurtenances for a special exception when they take up more than $25 \%$ of the roof area [5]. Such a restriction could effectively preclude roof top collectors in a limited number of situations. Therefore, it may be necessary for a number of cities to consider whether to make solar collectors a specific exception to height restrictions, and if so, whether to limit the area of the protruding collectors to a certain percentage of the total roof area [6].

Roof top collectors should easily comply with typical zoning ordinances, barring those dealing with aesthetic considerations. Control of aesthetics is increasingly accepted, at least de facto, as a permissible exercise of the state's police powers [7]. Aesthetic regulations can take the form of ordinances designed to protect historical districts [8], or regulations that require all structures in a particular zone to be architecturally compatible [9]. A city with valid aesthetic zoning controls must decide whether harmonious architectural styles are more important than the use of solar energy. The city of Coral Gables, Fla. banned roof top solar water heaters in the 1950s because the 
collectors were not considered aesthetically compatible with the city's architecture. However, the 1973 "energy crisis" caused the city to reevaluate its priorities, and it recently amended its zoning regulations to allow roof top collectors [10]. Even if a city is not willing to amend its aesthetic regulations, people who wish to use solar collectors can design their collectors to be congruous with architectural restrictions, possibly by shielding the collectors from view. The best solution may be a compromise, wherein communities allow solar collectors that have a minimal visual impact [11].

In some locations, because of the orientation or shading of a building, it may be desirable to place a solar collector on the lot instead of the building roof top. Such detached collector units may not comply with zoning ordinances in a number of localities. In one of the extremely rare reported cases involving solar energy collectors, a New York trial court upheld a town zoning board's denial of a variance to allow a detached solar collector to be placed in a front yard [12]. The New York case involved an ordinance that required a 50-ft-decp front yard, with no structures permitted in that space. There are analogous rear and sideyard requirements in many cities. Uther ordinancés specify what percentage of the lot may be covered by structures, or contain restrictions on what types of accessory uses are permitted in certain zones [13].

New construction may also face restrictions on the orientation of buildings that may cause a building not to be adaptable to solar energy usage [14]. Some subdivision regulations contain provisions that control the layout of new streets [15]. There may be provisions stipulating that new streets must align with existing streets. To provide good southern exposure for buildings, most new streets should run east-west. Under traditional siting of structures, the long axis of the residence would be parallel to the east-west street, resulting in maximum southern exposure. While many developers could voluntarily orient most streets in an east-west direction, it may be desirable for communities to amend their subdivision regulations so that they require east-west streets wherever practical [16].

Zoning regulations often control the orientation of the building in relation to the orientation of the street. Lot line angle requirements [17] sometimes stipulate that lot angles be perpendicular to the street. Often zoning ordinances will require a minimum lot frontage [18]. Lot frontage requirements, when combined with density requirements, have the effect of determining lot dimensions. If a $5,000-\mathrm{ft}^{2}$ lot is required, and there is a $50-\mathrm{ft}$ lot frontage required, lots will be $50 \mathrm{ft}$ by $100 \mathrm{ft}$. Once the lot dimensions and orientation have been determined, there is often little choice of where to place the building. Zoning ordinances of ten require specified setbacks from each lot line [19]. Thus, given a north-south street with perpendicular lot line angles, frontage requirements that result in wide, shallow lots, and regulations that require large front and rear setbacks, there would be no choice but to site a building on a north-south axis.

Methods of avoiding rigid siting and lot size requirements are currently available in many localities. In such areas, a developer may apply for a planned-unit development (PUD). PUD regulations allow great flexibility in laying out streets and siting buildings, and are an ideal device for orienting buildings so that they have a southern exposure [20]. Such flexibility is less available in developing a vacant lot that has already been plotted.

A property owner confronted with a zoning barrier has an opportunity to appeal to a board of adjustment for relief. One potential ground for appeal is that building of ficials misinterpreted the regulation, as the regulation was not meant to apply to the case in question [21]. If the board of adjustment agrees with the building official's interpretation, the property owner can ask the board of adjustment for a variance [22]. 
To be eligible for a variance, a person must show that his lot is uniquely situated so that application of the ordinance would cause him excessive and unique hardship [23]. In denying a variance petition that sought permission to place a solar collector in a front yard, a typical zoning board opinion was, ". . . there are no unusual circumstances and conditions affecting petitioners' property .... that are peculiar to said property and do not apply generally to other property in the vicinity" [24].

In general, the variance procedure may not be the appropriate mechanism for overcoming solar zoning barriers. However, zoning boards are notorious for their laxity in following mandated standards regarding variances [25]. Though technically solar collectors should not qualify for a variance in cases where the solar owner's property is not uniquely situated, it is quite possible that a sympathetic board of adjustment would grant a variance in any case. They may, however, put conditions on the installation of a solar collector in exchange for granting the variance. When such conditions are placed on the collector, the board of adjustment is, in effect, treating the collector as if it were a special exception.

Special exceptions (also called conditional uses) and variances are of ten confused. A variance is granted for uniquely situated land where the "letter" of the law, but not the "spirit," acts as an unwanted restriction on land use. A special exception is a statutory provision that allows an otherwise unlawful land use, when the specific statutory requirements have been met [26]. If a community wishes to allow solar devices, but does not want to repeal the restrictive ordinances, the proper device to use is the special exception, not the variance. While a board of adjustment may grant a special exception under the guise of a variance, it would be preferable to amend the zoning ordinances to specify that solar. collectors be considered for a special exception, and under what circumstances the special exception will be granted. For example, solar collectors could be a conditional use in neighborhoods subject to architectural controls. The statute could specify that the special exception will be granted when the collector is not visible, or is designed to be compatible with existing architecture.

As in the variance procedure, a property owner applies to the board of adjustment to obtain a special exception. However, unlike the variance procedure, where the property owner has the burden of proving that the zoning ordinance should not apply to him, the board of adjustment presumes that a person is entitled to a special exception if the listed statutory requirements have been met. Thus the special exception, by listing specific statutory criteria, allows a person to know in advance what he must do to be able to install the collector. The specific statutory listing of criteria is generally not required for variances.

From a community's perspective, the special exception may be preferable to changing zoning legislation to allow solar devices in all cases. The special exception allows cities to balance, on a case-by-case basis, any negative effects on public good resulting from use of a particular solar collector. By placing guidelines on special exceptions for the use of solar collectors, a community can fulfill the goals of its zoning regulations, while allowing enough flexibility to solar collectors regarding exact compliance with those regulations. The special exception process may be considered burdensome by property owners. However, if clear exception standards existed, a property owner could be confident that conformance with those standards would guarantee grant of an exception to his collector.

Another alternative for a locality desiring to remove zoning barriers to solar energy usage involves amendment of zoning ordinances. Solar collectors could be expressly 
excluded from all height restrictions, maximum lot coverage restrictions, and yard requirements. Whether used for heating or the generation of electricity, solar collectors could be declared a permitted use in all districts, and flexible setback regulations could allow proper orientation to any new building equipped with a solar collector.

However, it is quite possible that many localities would not wish to totally relinquish control over placement and use of solar energy collectors. For example, a model local ordinance developed for the city of Santa. Clara, Calif. recommends the following provision:
Use Permitted - The use of solar energy collectors for the purpose of providing energy for heating and or cooling is a permitted use within all zones, whether as a part of a structure or incidental to a group of structures in the nearby vicinity. Use of solar energy collectors is subject to the restraints imposed by the diversity of topography within the city limits plus the zoning, height and setback limitations contained within this Code and existing conif erous trees. No guarantee is hereby given that all property within the city limits of Santa Clara is entitled to the use of solar collectors. However, as a general policy, reasonable care should be taken to protect the opportunity for the utilization of solar collectors at all of the locations available. [27]

Such an ordinance clarifies that solar collectors are a permitted use, but does not eliminate other zoning regulations that could hinder the utilization of solar energy.

\subsection{RESTRICTIVE COVENANTS}

Private land-use controls can also be impediments to the use of solar energy. Covenants or equitable servitudes are of ten included in the deeds of new developments in order to control the use and appearance of all the lots in the development. Such restrictive covenants are enforceable either separately by other property owners in the development, or by a neighborhood association.

Restrictive covenants can regulate many of the same types of uses as zoning ordinances. Permitted accessory uses, yard requirements, percentage of lot coverage, heights of structures, and aesthetics can be controlled through covenants [28]. Often, proposed alterations or additions to any house in a development must be approved by either an architectural review board or the neighborhood association [29]. Such restrictions may hinder the installation of solar energy systems. For example, in Valencia, Calif., a property owner wished to install a solar collector on his roof. The property was subject to covenants prohibiting all roof top installations visible from neighboring lots or public streets. There was also a covenant requiring an architectural review board to approve all structural alterations as being consistent with the neighborhood's architectural style. Pursuant to these covenants, the review board denied permission to the property owner to install the collector. A court battle ensued, and the property owner ultimately prevailed [30].

Covenants can be modified or terminated by agreement of all parties subject to the restrictions [31]. Such an agreement could be difficult to obtain since any one landowner in the development can keep the covenant binding by refusing to agree to a change. Where neighborhood associations have the power to enforce the covenants, they can allow the installation of solar devices that do not strictly comply with the covenants. 
For example, in Anaheim, Calif. a neighborhood association pressured by the California Energy Commission reversed its own decision to reject a solar collector installation that did not meet the applicable restrictions [32]. Where a particular covenant is ambiguous, ". . . the construction consonant with the unencumbered use of the property will be adopted; any doubt therein is resolved against the enforcement of the restriction" [33]. However, use of such a vagueness argument would have only limited application. Many restrictive covenants which could bar the use of solar energy are carefully and specifically drafted.

Changed conditions may negate land-use restrictions when enforcement would cause excessive hardship without providing any benefit to adjoining property owners [34]. The changed conditions doctrine will be applied when:

the nature of the neighborhood has changed extensively. from that envisaged under the scheme of covenants, so that the purpose of the covenants has already been defeated-that is, so that the enforcement of the covenant would not provide the desired benefits for the plaintiff, while inflicting substantial loss on the defendant .... [35]

A classic application of this doctrine is Trustees of Columbia College v. Thatche [36]. An elevated train line was constructed next to a building that was previously restricted to residential use. Because the proximity of the train line made the property undesirable for residential purposes, and was unforseeable when the use restrictions were created, the court refused to enforce the covenant [37]. Since the changed conditions doctrine has heretofore been applied only to actual physical changes in the neighborhood, it is doubtful whether the courts would use a change affecting the entire nation (e.g., the shortage of fossil fuels) as grounds for not enforcing covenants. It is also questionable whether, at least in the near future, prohibition of solar energy use will be considered a substantial hardship. When conventional fuels become so expensive that use of solar energy would generate huge savings, changed conditions arguments may have more success.

Enforcement of a covenant might be avoided if it violates the public interest [38]. Such an argument was successfully used in the Kraye case [39]. However, in that case the California legislature passed a statute during the trial, voiding most of the restrictive covenants that limited the use of solar energy. Though the trial court did not rely on the presence of the statute, its existence limits the value of the case as precedent for other states.

Without a clearly defined statute of state public policy (e.g., California's), it is unlikely that a court would refuse to enforce a covenant on the grounds that the covenant conflicts with public policy [40]. It is possible that a court might not enjoin the installation of a collector that violates a covenant by limiting the remedy to one of damages [41]. A remedy of damages would allow a property owner to install a collector as long as he is willing to pay his neighbors for the damage he does to their property; i.e., the amount that neighboring property values decline because of the installation. Since damages might be small, limiting remedies soley to damages could be a significant victory for a property owner who installs a collector despite restrictive covenants. 
Other states can follow California's example in using legislation to void restrictive covenants. The California law voids all covenants that restrict the use of solar energy, unless the covenants are "reasonable restrictions" [42]. Reasonable restrictions are defined as those that do not significantly increase the cost or decrease the efficiency of the system, or those that allow an alternative system of comparable cost and efficiency.

It has been contended that although a community can legislatively strike down restrictive covenants, it must compensate those who are burdened by the covenant's removal. Unlike other land-use regulations where compensation is required only when the statute is found to be a taking, the legislative taking of a covenant automatically requires compensation [43]. Unlike zoning, covenants are considered a vested property right.

The actual compensation for legislatively invalidated convenants may prove to be nominal. The usual test for determining the amount of compensation is to compare the value of the property with and without the covenants. Since property may be more valuable if convenants restricting solar use are elimated, these covenants may require no compensation.

\subsection{NUISANCE LAW}

The law of nuisance is another type of restriction on land use that could affect solar energy utilization [44]. Nuisance law should not prove to be a hindrance to the collection and utilization of energy from sunlight although it might be a barrier to the use of wind energy conversion systems[45].

Nuisance law examines the reasonableness of a particular land use in relation to surrounding land uses [46]. There are two conceivable ways in which a solar collector could be considered a nuisance. The first would be where a collector is perceived by surrounding land owners as an aesthetic nuisance. However, aesthetics are not usually accepted as a grounds for a nuisance action [47]. Another conceivable nuisance theory would claim that a collector is producing excessive glare and discomforting neighboring landowners. While such an action could possibly succeed, it is doubtful that a solar collector would cause excessive glare. The angle at which collectors are usually placed would be too steep to cause significant glare at ground level. Further, collectors generally are designed to absorb light, not reflect it.

Wind generators could possibly be considered a nuisance in some cases. Unlike sunlight collectors, wind generators have exposed moving parts that are potentially dangerous. If a blade from such a generator disengaged while turning at a high speed, it could cause property damage or personal injury. Operating wind generators usually produce a whistling noise and may also cause increased ground wind speeds on adjoining property [48]. These potential harms would have to be weighed against a generator's benefits, to determine if a nuisance exists. A wind generator's location, the severity of the risks involved, and annoyances the particular system created would be significant factors in any decision. 


\section{SECTION 3.0}

\section{CHARACTERISTICS OF A DESIRABLE SOLAR RIGHT}

The most widely discussed legal question concerning solar energy is the question of how to secure access to the needed sunlight [49]. The problem usually focuses on collectors for active solar heating and cooling systems, but exists for passive solar systems as well. Access to wind for wind energy generators is an analogous problem. Proposed solutions to the solar access dilemma are proliferating in legal publications, governmentcommissioned studies, and land-use planning literature [50]. This paper evaluates desired characteristics of a scheme to secure solar access, as well as suggested approaches utilizing those characteristics.

As William R. Harris said in a statement before a California legislative committee considering solar access legislation:

The inadequacy of California's regulatory framework in facilitating and safeguarding a property interest in sunlight is by no means the primary impediment to solar energy development. The relatively high cost of solar heating, and even higher cost of solar cooling deter even those potential customers who are aware of life cycle costs. Lack of a legally-protected interest in sunlight is not the primary impediment but may be a sufficient impediment to widespread solar heating and cooling outside rural and new subdivision areas. [51]

A property owner must be assured of access to solar energy before installation of a solar energy system [52]. A potential solar user will be deterred from making an investment in solar energy systems if he is faced with the uncertainity of a neighbor building a tall structure or growing trees that could shade a collector.

An ideal solar access scheme should also minimize the hardship to land owners adjacent to the property using solar energy. This is important in assuring the constitutionality of any legislated regulation that secures access through uncompensated restriction on land use.

Minimizing the procedural burden on the person seeking secure access is also desirable. This would be facilitated by having the solar access "given" by a zoning regulation restricting property, rather than requiring a long, expensive, application process to secure access. Any system that requires property owners to initiate negotiations with neighbors or to go to court in order to secure solar access, involves procedural burdens.

Mechanisms for securing solar access should be flexible. Though secure solar access may be important in conserving nonrenewable fuels, there should be sufficient flexibility so that development is not inappropriately restricted, or legitimate planning goals needlessly sacrificed. For example, a well-planned city may require an area where highrise structures may be built. A system of solar rights should not make that goal legally impossible. 
The desirability of any scheme to ensure solar access also depends on the ease with which a solar access law can be administered and enforced. Often, administrative costs can be lowered only at the expense of increasing the burden on people wishing to install solar collectors, and their restricted neighbors. For example, declaring all shading to be a public nuisance would not require administration by a bureaucracy, but would be overly burdensome on property owners who must go to court to clarify their rights. Ease of enforcement and administration is facilitated by clear, well-publicized rules; e.g., a zoning ordinance would be easier to administer if property owners knew how to shape their land use to comply with the zoning requirements.

One solution to the problem of securing solar access cannot be expected to meet all the desired criteria in all situations. Trade-offs are necessary. A case-by-case determination of who is entitled to solar rights provides important flexibility, avoids some excessive hardship, but also has high administrative costs. It may be that broadly applicable, relatively inflexible rules are more appropriate in certain areas of a city; while greater flexibility is crucial in other areas, even if it results in high administrative costs. 


\title{
SECTION 4.0
}

\author{
SOLAR ACCESS
}

\section{I COMMON LAW MECHANISMS TO SECURE SOLAR ACCESS}

In the absence of statutes or private arrangements, the common law allocation of rights to sunlight governs. In the United States, one does not generally have a common law right to receive sunlight that crosses through another's airspace [53].

The Doctrine of Ancient Lights is a type of "prescriptive easement" that is recognized in England [54]. A prescriptive easement allows a property owner to acquire a right to limited use of another's property by having openly and adversely used that property for a certain period of years [55]. A classic example would be open use of a neighbor's footpath for the required statutory period (usually between 10 and $20 \mathrm{yrs}$ ) from which an easement to use that footpath may arise by prescription.

One reason the Doctrine of Ancient Lights has not been used in the United States is the general reluctance of U.S. courts to recognize negative prescriptive easements [56]. In the footpath example, the easement that was created by prescription was "affirmative;" it entitled the property owner to enter and to make use of his neighbor's property. A "negative" easement, by contrast, restricts what a person is allowed to do with his property. Negative easements restrain a property owner from legally stopping someone from acquiring the easement by continued use during the prescriptive period. In the footpath case, a person could use the laws of trespass to stop someone from using the path before a prescriptive easement would arise. However, a person cannot go to court to stop a neighbor from using the light that crosses through his airspace. Were negative prescriptive easements generally recognized, an owner of property adjacent to a solar collector would be forced to obstruct light needed for his neighbor's collector to prevent the creation of an easement. In a sense, therefore, recognition of negative prescriptive easements may actually be counterproductive. Such easements might induce shading of solar collectors that would not have been obstructed if there were no possibility of obtaining an easement by prescription.

In England, the Ancient Lights doctrine was altered to allow property owners to file a form stating their desire to maintain their right to obstruct a neighbor's light. This was done to alleviate the burden placed on property owners who wished to prevent neighbors from acquiring easements to light and air. While such forms would eliminate the problem of people shading collectors solely to prevent an easement from arising, the net result might be minimal protection for solar collectors. Property owners might quickly file forms to protect the value of their property.

Even without the practical difficulties discussed previously, negative prescriptive easements would not be desirable as a mechanism for securing solar access. It is necessary to wait out a prescriptive period before one is assured of solar access. Thus, certainty of access at the time of installation would be impossible. Even though courts have rejected the Doctrine of Ancient Lights, such a doctrine could be enacted by $a$ 
legislature. However, such a doctrine is not very useful or effective as a means of securing solar access.

Prescriptive easements could prevent vegetation from shading collectors. Since it might take years for a trees to grow tall enough to obstruct the needed solar energy, a property owner could install a collector with some certainty that he would be able to obtain a prescriptive easement before an obstructing tree could be grown. Such prescriptive easements, recognized only against shading from vegetation, could be combined with zoning regulation of the size and placement of structures. The desirability of this limited use of prescriptive easements would depend on whether the prescriptive period was short enough to allow prescription before new trees could grow enough to shade the collector.

The common law doctrine of private nuisance has been mentioned as a possible method by which secure solar access could be obtained 157 . However, as a person has nn right to light and air coming across adjacent property, it would be surprising if a court declared that obstruction of light or air is a nuisance [58].

Even if such shading were a nuisance, a landowner who relies on private nuisance for securing access would not be assured of access until long after the system were installed. In addition, the necessity of going to court to secure a solar right would place a fairly great burden on those wishing to secure solar access.

\subsection{CONTRACTUAL SOLAR ACCESS}

Though an owner of a solar energy system cannot rely on nonconsensual common law doctrines to provide him with secured solar access, he rean nften nhtain it by purshasing the needed easement from adjoining property owners, The law recognizes express negative easements for light and air [59] as a property interest in the airspace of his ncighbor $[6,0]$.

Several states have now passed legislation that recognizes the validity of easements for solar access [61]. Such statutes usually list required elements to be included in the document granting the easement, such as the angles of skyspace, the duration of the easement, the consideration given for the easement, and whether the easement shall bind subsequent owners of the burdened and benefited estates. There are also recording requirements in the statutes. The purpose of the statutes is not only to remove doubt as to the legal validity of such easements, but also to clarify procedures for creating the easements, in some cases eliminating the need for a property owner to rely on legal counsel [62].

Privately negotiated easements have many highly desirable characteristics as mechanisms for securing solar access. Even in states that have not passed easement legislation, such an easement will be recognized if the terms are clearly written and recorded [63]. Privately negotiated easements require no administrative bureaucracy and 
no costly planning studies before they can be implemented. They rely on private enforcement. Express easements also allow for flexibility. In areas where high-rise development is allowed, it is unlikely that a property owner would sell an easement to the airspace over his property. Easements would be expected to be granted only in areas where they would not be a great hardship to the burdened estate. Thus, the easements would not likely hamper a city's development. Property owners granting easements would be compensated by an amount equal to the burden placed upon them.

However, the very qualities that make consensual easements desirable (i.e., their essentially private, voluntary nature) present problems for anyone desiring to secure solar access. Where the neighbors are not on friendly terms, or possibly when the neighboring property is owned by an absentee investor, the need to initiate negotiations may hinder investment in solar equipment. Easements may prove to be too expensive for someone wishing to secure solar access. Where the easement would threaten the development potential of neighboring property, it may be that solar access is inappropriate from the perspective of maximizing the public good. However, there may also be cases where the easement's costs are not due to its real value, but rather to a neighbor holding out for an unreasonably high price.

To determine whether the availability of consensual easements is adequate for securing solar access, a city must first decide if the use of solar energy produces a public benefit. In that case, a city may decide that promotion of such a public benefit might justify shifting some of the burden and expense of solar access away from users of solar energy, to adjoining property owners or society as a whole. This would be accomplished by new legislation. A city may also decide that easements are an appropriate mechanism in existing neighborhoods, and that any legislative schemes for securing solar access are to be used in new developments only [64].

One possibility for easing the burden on owners of solar equipment would be to use the government's power of eminent domain to assist in acquiring easements. A solar owner unable to privately negotiate the needed easements could apply to the appropriate administrative agency, which would determine whether the desired solar access would promote the public welfare [65]. If so, the agency would condemn the airspace needed for the easement and give just compensation to the burdened property owner. The cost of the compensation could then be assessed against the benefited property owner [66]

Such a scheme shif ts part of the procedural burden from the person seeking solar access onto the city, while still limiting administrative costs by requiring property owners to first seek easements through private negotiations. Although adjoining neighbors may have to accept restricted use of their property involuntarily, they would be compensated for their loss. Flexibility would be preserved since the city could consider the variables of each request before deciding to use its condemnation powers. Property owners obtaining solar access through this type of condemnation might be permitted to pay the cost of the easement over time, which would limit the initial investment required by solar equipment [67].

Restrictive covenants, previously discussed as potential barriers to solar access [68], could instead be drafted for the purpose of protecting solar access; controlling height and 
placement of vegetation and structures on adjoining property. Like easements, covenants are enforced by the property owners who benefit from their existence. The administrative costs of relying on covenants to secure access are minimal. The utility of restrictive covenants as a method of securing solar access is probably limited to new developments where the developer chooses to include uniform covenants in all of the deeds. It is unlikely that a group of property owners would otherwise voluntarily agree to restrict the development and use of their land for their neighbor's benefit. If one property owner in a neighborhood refused to consent to the restrictive covenants, his neighbors-obtaining no benefit from the covenants themselves-would probably not agree to accept the burden of those covenants.

\subsection{PRELIMINARY CONSIDERATIONS TO LEGISLATED SOLAR ACCESS}

Although easements can be an effective means of securing access to solar energy, the costs of obtaining them can be expected to decrease the demand for solar systems. A state desiring to promote use of solar energy could consider legislative mechanisms for securing solar access at little or no cost to the users of the solar energy [69].

Although the Federal Government arguably has the power to legislate in order to secure solar access [70], solar access legislation would most likely be passed on the state and local levels. While the states' powers would be limited only by constitutional constraints, local levels of government must first consider if state enabling legislation allows them to act [71]. Standard state zoning enabling acts do allow localities to control the height and setback of buildings which solar access zoning would need to control [72]. To eliminate any question of whether localities have the power to zone for solar access, Minnesota amended its zoning enabling legislation in 1978 [73], to specifically allow both zoning and subdivision regulations to control land use to provide "access to direct sunlight for energy systems ..." [74].

While a locality's zoning powers may include authority to protect solar access even without explicit reference to solar access in the enabling legislation, it is doubtful that such authority would include power to actually allocate solar rights without state legislation explicitly enabling it to do so. Unlike zoning, an allocation of solar rights creates a property interest in the solar energy needed for a collector. Once created, such property rights would be relatively immune from further governmental action and would not fall under the powers to control land use that are normally delegated by the states [75]. 


\title{
SECTION 5.0
}

\section{CONSTTTUTIONAL CONSIDERATIONS}

For the exercise of its land-use regulation powers to be contitutional, a state-or a locality acting within the scope of state enabling legislation-must be promoting the public health, safety, morals, or general welfare [76]. Commentators addressing the constitutionality of solar access legislation agree that the goal of promoting solar energy utilization should justify use of such powers [77]. There is a judicial presumption favoring the validity of any particular goal legislatively declared to be in the public interest [78].

There are constitutional limits on the methods that can be used to serve even a concededly proper land-use goal. The equal protection clause of the Constitution [79] requires that similarly situated people be treated in a similar manner. The benefits and burdens of the legislation cannot be randomly or arbitrarily provided. The constitutional requirement of substantive due process [80] requires a rational relation between legislative goals and the means chosen to reach those ends. The means chosen need not be necessarily the best possible method for achieving the desired goal. In fact, the United States Supreme Court has declared that there need be only a minimal relation between the ends and the means [81].

Finally, the Constitution will require that solar access legislation not "take" private property without compensation. At what point a regulation, which restricts land use, becomes a taking requiring compensation is a most difficult and widely discussed question of law [82]. Under one test used to determine whether a regulation is a taking, one would look to see whether the restriction was designed to prevent a nuisance-like activity, which would not require compensation, or whether it was designed to promote a public benefit, which would require compensation [83]. Using that test, solar access legislation might require compensation; since shading of solar collectors is not usually considered a nuisance-like activity [84]. This approach to determining when a regulation is a taking has been criticized, and does not explain the outcome of many cases [85]. One prominent commentator has concluded:

\begin{abstract}
the only 'test' for compensability which is 'correct' in the sense of being directly responsive to society's purpose in engaging in a compensation practice is the test of fairness: is it fair to effectuate this social measure without granting this claim to compensation for private loss thereby inflicted? [86]
\end{abstract}

The greater the burden imposed on landowners by any legislation, the more likely that the legislation constitutes a compensable taking. A mere diminution in property value does not itself prove that there has been a taking, as long as the governmental action has left the property owner the right to put his land to some reasonable use [87]. Under this test, a solar access law that seeks to minimize hardship to adjoining property owners could constitute regulation that is permissible without compensation. This would be the case when the burden a property owner suffers from solar access legislation is offset by the benefit he receives because similarly situated land is also similarly restricted [88]. Under the usual zoning ordinance, for instance, all parcels are restricted, and thus 
burdened, but all parcels also benefit from the restrictions placed on the adjoining parcels. If land were zoned for solar access, the development potential of a property owner's land might be limited, but he would also gain secure solar access for his own property. By contrast, under a system that allocates solar rights upon application by collector owners, burdened land may not receive a direct benefit in return. The takings issues raised by such a system could be troublesome. 


\section{SECTION 6.0}

\section{COMPREHENSIVE PLANS}

Constitutional difficulties with solar access legislation may best be avoided by including solar access considerations in the comprehensive or master plans of areas affected by the legislation [89]. While in most states the comprehensive plan itself has no legal effect, it is extremely useful in defending against constitutional challenges to legislation. Ideally, the plan would detail ways in which the legislation would promote public welfare and would formulate standards, principles, and proposals for implementing the plan's objectives [90]. By explicitly stating criteria used to determine which land will be provided with secure solar access, a city can show that all similarly situated land-owners are being treated in a like manner. This would be consistent with constitutional requirements of equal protection [91]. Assuming the actual legislation reflects the planning and research that went into formulating the comprehensive plan, the rational relation between the stated legislative goals and the means chosen to reach those goals should thwart any substantive due process challenge to the legislation.

The comprehensive plan can also minimize the risk that the legislation, as generally applied, or applied to a specific parcel, would be considered a taking without just compensation. As part of the planning process, the benefits of secure solar access should be weighed against the burden such legislation will cause adjoining landowners. The plan will specify which areas within a community will be appropriate for solar access legislation. The plan may include a mechanism for relief to landowners who are excessively burdened, including criteria for determining which landowners should be relieved-either via compensation or by exemption from regulations limiting their land uses. If done properly, the plan should lead to legislation that will not cause burdens disproportionate to the benefits promoted by the legislation.

The comprehensive plan might include studies detailing the harms caused by society's reliance on fossil fuels, such as environmental damage, an unfavorable balance of trade, and reliance on foreign countries for energy supplies. The plan could contain studies showing the benefits which will accrue from use of solar energy. The plan should also explain the necessity of securing solar access in order to promote and accelerate the utilization of solar energy. Such information in the plan is useful in showing that securing solar access is a legitimate use of a state's police powers [92].

The comprehensive plan serves other purposes besides protecting against constitutional challenges. Many preliminary considerations need to be analyzed prior to the implementation of solar access legislation.

One critical preliminary issue is the proper level of solar access to be provided. The American Society of Planning Officials (ASPO) lists four types of solar access: (1) rooftop protection; (2) south-wall protection; (3) south-yard protection; and (4) detached collector protection [93]. By securing south-wall protection, a legislature would be promoting both active and passive solar technologies. Protection of rooftops would mainly promote active systems. 
It may be that a certain level of access cannot be provided without causing excessive burden to some. It may be more burdensome to guarantee roof top protection in one case than to guarantee south-yard protection in another. Thus, the plan may conclude that it is better to equalize the burden on all property owners, even if many locations will not receive guaranteed sunlight. Under such a plan, the level of access might be determined by how closely structures on adjoining lots are located to each other.

It is also important for the regulating municipality to consider the trade-offs necessitated by solar access legislation; e.g., how much solar access legislation will affect the number of shade trees in a community. The plan would weigh the benefits accruing from tall shade trees, (such as keeping buildings cool in the summer, and their more intangible quality of making cities more liveable) against any limitation on the growth of shade trees under the proposed solar access law.

The comprehensive plan should also analyze the long-term effect of solar access legislation; i.e., whether solar access legislation will cause urban sprawl resulting in more fuel being required to supply the increased transportation needs, compared to that being saved by the use of solar energy. 


\section{SECTION 7.0}

\section{ZONING FOR SOLAR ACCESS IN EXISTING NEIGHBORHOODS}

Mechanisms to secure access in existing neighborhoods probably differ from those most appropriate in developing neighborhoods. Guaranteeing solar acess through site selection or restrictive covenants in new developments is not available in existing neighborhoods.

Present zoning regulations of ten site houses far enough apart that shading by buildings is not a problem [94]. Thus, in many existing areas, the only shading problems of concern to solar users would be caused by vegetation. Though trees are not normally covered by zoning restrictions, there appears to be no reason why they could not be. If the public welfare would be promoted through restrictions on trees, the same police powers which allow the state to mandate such things as height and setback restrictions on structures should allow such restrictions to apply to vegetation [95].

A number of zoning techniques have been proposed to provide some level of secured solar access in existing neighborhoods [96]. Prescriptive zoning ordinances use detailed height, setback, lot coverage, and other such requirements. The best technique for using prescriptive zoning to secure solar access is called bulk-plane zoning, or building envelopes [97]. Under this type of zoning, the maximum height of a structure increases as the structure is placed further from the lot line. Bulk-plane zoning in New York City resulted in what was called "wedding cake" architecture, as the higher portions of the building had to be increasingly narrow [98].

Albuquerque, N.Mex. has enacted a bulk-plane zoning ordinance to protect solar access, and other cities, including Atlanta, are considering it [99]. The Albuquerque ordinance allows a certain base height for a structure located anywhere on the lot within normal setback requirements. The building is allowed to exceed that height so long as all portions of the building remain within a pyramid formed by $45^{\circ}$ angles rising from the lot lines. Once the basic building bulk and shape that can be contained within the pyramid is determined, the ordinance allows the owner to move the structure to the south, east, or west [100]. The Albuquerque zoning was implemented in both high density residential areas and some nonresidential areas. It was not implemented in low density residential areas because existing zoning was considered adequate to prevent structures from shading the rooftops of adjoining structures. The ordinance does not restrict trees, although some limitation must be placed on vegetation [101].

Rather than specifying the exact bulk allowed, it is possible to specify the performance that must be met by structures. Such regulation would simply prohibit more than a certain amount of shading of collectors on adjoining property, leaving it to property owners to calculate height of buildings and locations for planting vegetation: The University of New Mexico has proposed a type of performance-standard solar zoning regulation, and the city of Los Alamos, N.Mex. has adopted it [102]. 
The University of New Mexico proposal is actually a combination of prescriptive and performance standards. All lots are allowed to cast shadows on property to the north, as long as the shadows do not protrude into neighboring property more than would the shadow cast by a hypothetical fence on the northern lot line, as detailed in the statute. The length of permitted shadows would be measured between 8:00 a.m. and 4:00 p.m. on December. 21, the day in which shadows are longest. The height of the hypothetical fence is adjustable based on the amount of solar access to be protected. A lot would be allowed to obstruct more sunlight than would the statute's hypothetical fence only where the extra shading does not deprive a collector of needed solar energy. There are also requirements that all collectors must be placed in a reasonable manner, to minimize the burden on adjoining landowners.

Using hypothetical fences is really a type of bulk-plane zoning. Starting at the top of the hypothetical fence, one could construct a hypothetical plane rising to the south at an angle equal to that of incoming sunlight on December 21. Such a plane would define a three-dimensional building envelope within which building and vegetation are allowed, regardless of effects on neighboring solar collectors. For structures or vegetation rising above the building envelope, the statute requires that the structure or tree "perform" in a certain manner; namely that the tree not cast a shadow on a reasonably placed solar collector during certain hours of the day.

The bulk-plane zoning ordinance, or a type of performance standard zoning, would be primarily useful for new development or redevelopment in a district containing the restrictions. Any buildings built prior to implementation of the ordinance would be considered preexisting, nonconforming, structures and are usually not required to comply with the ordinance [103]. The impact of zoning regulations to protect solar access in such areas would be to restrict the height which could be added to a building.

However, if vegetation is included in the zoning restrictions, as in Los Alamos, the new zoning could have a large impact on existing neighborhoods, depending on whether a broad exemption for preexisting nonconforming trees is created. One could define nonconforming trees as trees which already exceed the height limitations. Alternatively, all trees planted before the enactment of the ordinance could be exempted. If the former approach is adopted, it would mean that some trees would require frequent trimming or future removal. Even if such a requirement is politically acceptable, it may establish an unconstitutional taking. It is questionable whether a property owner could be forced to pay the cost of required tree-trimming [104].

Aside from the problems of vegetation, zoning changes to secure solar access in existing neighborhoods could trigger other difficulties. Prescriptive standards would require large planning costs and might not allow sufficient solar access in some locations, while overly restricting other property. Special exceptions or variances could be used to provide some flexibility, but only at an increased administrative cost. Performance standards would allow heights to be better tailored to fit the actual access requirements of individual neighboring collectors. However, performance standards require some mechanism to ensure that neighboring collectors are placed in a reasonable location. The reasonableness of a collector's location could be a difficult issue in cases where the collector could be moved to a higher location, but at a substantially increased cost. 
In the proposed New Mexico zoning ordinance, the solar access restrictions apply only to properties adjacent to existing collectors [105]. Atlanta's proposed prescriptive standards are applicable regardless of whether the adjoining property owner has installed a collector [1 06].

The New Mexico approach has the advantage in that it does not needlessly restrict development or growth of vegetation. That same advantage could also be gained through a special exception process whereby development that will block sunlight is allowed, but only if adjoining property to the north is not suitable for solar retrofit due to building orientation or existing shading of possible collector locations. Such a special exception, however, adds administrative costs to the zoning scheme and is more burdensome to property owners than New Mexico's approach. The proposed New Mexico approach could accelerate solar energy system installations. Under this approach, a property owner knows that if he waits to install a collector, he may lose access because his collector location will have been previously shaded by his neighbor.

Many localities may prefer to protect access for future installations rather than to provide this crude incentive to install collectors immediately. Under such broadly applicable restrictions, the municipality runs a risk that some property owners may be needlessly burdened. However, such a risk may be necessary. to avoid a challenge to the rezoning on grounds that it creates spot zoning [107]. Zoning regulations are not allowed to single out certain parcels and treat them differently from the surrounding property unless the general public welfare, as distinguished from private interests, is promoted. In effect, the validity of rezoning isolated parcels will be determined by weighing the public benefits of the rezoning against all effects (positive and negative) on private interests.

One means of providing flexibility is to make the solar rights created by zoning transferable [108]. This would allow a property owner (wishing to be free of solar zoning restrictions) to purchase from his neighbors their right to unobstructed sunlight. The New Mexico plan includes such a transferability mechanism [109].

In some cases, the most beneficial use of land requires its development. The market in solar rights would determine when development is worth more than secure solar access. When development is more valuable than secure solar access, a transferability system would allow the access right to be sold to allow development, resulting in more efficient land use. The weakness of this argument for transferability is that the benefit a property owner enjoys from solar access-which is the only benefit that would be measured by the market mechanism-would not reflect the additional value of the public benefit in securing solar access. 


\section{SER}




\section{SECTION 8.0}

\section{ALLOCATED SOLAR RIGHTS}

Zoning for solar access does not provide certainty that solar access will be secure for the lifetime of the collector, as do other methods of securing access. Easements, for example, create a property interest in the right to light which is more secure than the zoning benefits that remain vulnerable to future zoning changes [110]. Legislative creation of a property interest in secure solar access has therefore been proposed as an alternative to solar access zoning [111]. The property interest would be allocated to any property owner meeting statutorily specified qualifications.

Legislation could declare that negative easements to direct sunlight can be acquired via prescription, by open use of specified types of solar collectors for a certain prescriptive period. However, as discussed previously [112], the lack of secure access prior to installation is a serious drawback to any system based on prescription.

There have been proposals to legislatively create a property interest in solar access prior to installation of a solar system. Under these proposals, a property owner applies to the proper agency for a solar right, which will be granted only if the property owner meets specified conditions. Such a system would require specific enabling legislation in order to be enacted at a local level, as it would not fall within a state's zoning enabling legislation. Once a locality had sufficient authority to allocate solar rights, it would be wise to specify in the comprehensive plan, the conditions attached to the allocation and the districts in which these rights would be available [113] .

Sunlight could be allocated by a system analogous to the prior appropriations doctrine [114] used for allocating water rights in some states. While the analogy to the prior appropriations doctrine has been widely criticized [115], a system based on such an analogy could produce results similar to any of the other solar rights systems which have been advocated.

The usual elements required for acquiring water rights under the prior appropriation doctrine are:

the intent to appropriate, notice of the appropriation, compliance with state laws, a diversion of water from a natural stream, and its application, with reasonable diligence and within a reasonable time, to a beneficial use. [116]

Criticism of the prior appropriations analogy to solar access has focused on its inflexibility [117], the ineguity of allocating rights on a first come, first served basis [118], and possible constitutional problems.

An allocation system based on prior appropriations can be flexible. The element of the prior appropriations analogy that has potential for great flexibility is the requirement 
that the natural resource be put to beneficial use. The criteria and standards for beneficial use could be encompassed in a comprehensive plan. Such a system offers maximum flexibility. It is possible to examine on a case-by-case basis the merits of having secure solar access as opposed to leaving the development potential of the adjoining property as it is. Thus, a solar collector on a small building in a high-rise district could be treated as a nonbeneficial use of sunlight. The idea of allocating sun rights on a first come, first served basis is not unique to schemes based upon the prior appropriations doctrine. We have already reviewed solar zoning proposals that only protect access for existing collectors [119]. It seems unlikely that any scheme of allocated sun rights would grant solar access permits when a building on adjoining property is obstructing sunlight. Permits might be granted in cases where only vegetation is obstructing sunlight. The prior appropriations doctrine can accomplish these same results. To gain a water right under prior appropriation, there must be a diversion of the water. The suggested analogy to diversion of water is the collection of the sunlight [120]. Vegetation could be defined as an insufficient diversion of the sunlight to be considered an appropriation. 'I'he owner of a solar collector shaded by trees would still have the opportunity to appropriate the access right [121].

There are drawbacks to developing a solar access permit system analogous to the prior appropriation doctrine. The familiarity of courts with the prior appropriations doctrine [122] has probably been overstated. Experience in allocating water rights does not help a court to decide whether a particular solar energy system is a beneficial use of the sunlight or to determine what type of collectors constitute sufficient appropriations of the sunlight. An analogy to the prior appropriations doctrine would not be useful in overcoming a challenge to a system of allocated sun rights on grounds that it "takes" private property without compensation [123]. In water law, the prior appropriations doctrine is used to settle disputes between claimants to the right to beneficially use water. When water is in short supply, competing rights to use the water are decided by the maxim, "first in time, first in right." There is no problem of governmental taking of private property without compensation, since one's right to water is always contingent. upon there being sufficient supply to satisfy prior appropriators. In other words, no vested property rights are affected when another appropriates a water right.

However, a vested property right will be affected in allocating sun rights. Granting a property owner a right to solar access is, in effect, restricting the use of adjoining land. Restricting development of one parcel in order to secure solar access for an adjoining parcel might be seen as depriving the owner of the restricted property, not of his sun rights but of the right to develop his land. The government could be seen as taking away traditionally recognized development rights in order to create rights to solar access not recognized by common law. The prior appropriations analogy would try to cast this analysis in terms of "who has the sun right-the owner of the collector, or the owner of the high-rise apartment?" The government cannot take a right a property owner never had. Under a strict analogy to the prior appropriations doctrine, one would have the right to build a high-rise only if the sunlight it would block had not been previously appropriated. But because the access rights depend for their existence on some earlier taking of a long recognized (though possibly unexercised) development right, a strict analogy to the prior appropriations doctrine is probably incorrect.

The takings problem in either a system based on prior appropriations or on some other type of application process, could be avoided by compensating the owners of burdened 
properties [124]. However, the expense of compensation, combined with the administrative costs of such a system, may make such a scheme politically. unacceptable. Compensation may be unnecessary if the system for allocating solar rights ensures that the burden placed on individuals is proportionate to the public benefit, and that no landowner is being deprived of all reasonable use of his land.

In many ways, a system of allocated solar rights is similar to solar access zoning. While allocated solar access property rights are more secure than access gained through zoning, there are ways to enhance the security of zoned access rights [125]. Allocation of access, because of its case-by-case decision process, has greater flexibility than zoning. In some areas, flexibility may be more important. In other areas, uniform lot size requirements, and height and setback regulations may eliminate the need for flexibility. In such areas, zoning would be easier to administer and therefore preferable to using a system of allocated solar access permits.

Another method for securing solar access that has been discussed and implemented in one case, is to declare any shading of solar collectors to be a public nuisance [126]. In effect, such a declaration is equivalent to allocating a right to secure solar access to everyone. It is highly undesirable because there is no method for providing flexibility or for avoiding excessive hardship. Use of the public nuisance doctrine can be modified to provide greater flexibility. The legislature could declare that shading is a nuisance only in certain districts, when the collector was unshaded when first installed, and/or when the collector has been located so as to minimize its potential to be shaded. Still, enactment of such a public nuisance doctrine would leave a landowner uncertain of whether he had a right to secure solar access before installing a system [127]. 


\section{SEPR}




\section{SECTION 9.0}

\section{TRANSFERABLE DEVELOPMENT RIGHTS}

Transferable development rights (TDRs) [128] have been discussed in conjunction with schemes for allocating solar rights, or zoning for solar access. The idea behind TDRs is that the development potential of a parcel of land be recognized as a separable property interest. It could be transferred to the owner of another parcel of land, thereby increasing the development potential of the transferee's parcel [129]. The concept was originally designed to provide a type of compensation, to owners of property which were valued as historical landmarks. Often these buildings, such as New York's Grand Central Station, are located in districts where zoning ordinances allow much greater heights and bulks than actually used by the historical structure [130]. When a historical building is to be preserved, the owner of the building may be deprived of its development potential. Rather than forcing the owner to bear the loss himself, the owner is allowed to transfer his unused development potential (i.e., the difference between the height of the present building, and the height to which zoning would normally allow the same parcel to be built) to other nearby parcels of land. The parcel of land to which the TDRs are sold may then be built to heights in excess of the zoned restrictions by an amount equal to the TDRs purchased.

As in the historical preservation situation, securing solar access in existing neighborhoods could threaten some development potential of affected land. However, a large loss of development potential is unlikely under most proposed legislative schemes to secure solar access. It is improbable that well-designed solar access legislation would apply to areas where existing comprehensive plans allow high-density building. If the legislation only restricts development in areas currently zoned for medium to low density, the lost development potential of the restricted property is not likely to be large.

Even if a city decides that lost development potential is so large that it would be unfair to force the restricted property owner to bear the burden, TDRs may not be the best method of compensation. In using TDRs in the historical preservation context, development potential is only transferable to owners of nearby parcels of land. This leaves the overall maximum density of the neighborhood unchanged, and one goal of the zoned height restrictions would remain fulfilled. If an area of a city is deemed to be appropriate for solar access legislation, however, it would make no sense to allow TDRs to be purchased within that area, thereby allowing some nearby parcel to have a building that obstructs a greater amount of solar energy.

It also makes little sense to allow TDRs to be transferred to a part of the city not suitable for solar access. In a high density area unsuitable for solar access, a city might still want to place some limit on the height of buildings. 'The city would have to set the height restrictions artificially low in the density area so that an influx of TDRs would not cause grossly excessive density in the area. The ultimate effect of such a system could be to force property owners in dense areas to bear the burden caused by solar access legislation. If the burden of securing solar access should not be borne alone by the owners of restricted property, then it seems most equitable to have society as a whole bear that burden, not just the landowners who acquire the TDRs. 
SER 


\section{SECTION 10.0}

\section{SOLAR ACCESS IN NEW DEVELOPMENTS}

In new developments, access problems may be avoided through siting of buildings and vegetation. All the land in a new subdivision can be restricted with covenants at the time of development, thus avoiding frustration of homeowner expectations. Subdivision regulations may need to be altered so that more houses will be built on an east-west axis. Official maps may also need to be changed to allow streets to run in an east-west direction where possible.

To provide secure access in new developments, all of the techniques discussed in the section on existing neighborhoods could be applied. Bulk-plane zoning could be used in new developments to insure that no buildings will obstruct excessive amounts of sunlight and that no large trees will be planted near the northern edge of any property. Setback regulations could be modified to allow zero lot line setbacks from the northern lot line [131]. Such a technique would allow property owners to control a greater amount of the land immediately south of a collector, minimizing the need to interfere with the use of other property in order to obtain solar access. The main drawback to zero lot line setbacks would be that houses on the south side of the street would have no front yard. It is questionable whether a city would want houses located that near the streets or that people would want to live in such houses.

In new developments, it would be possible to use traditional zoning to control the bulk and siting of structures and uniform restrictive covenants to control vegetation. The inclusion of specified covenants in the deeds can be required by local subdivision regulations [132]. Covenants are a highly desirable method for controlling vegetation without triggering high administrative costs.

It is also possible to use more flexible techniques in new developments. Planned-unit developments (PUDs) have been called an ideal device for designing a community to accommodate solar access without needing to change existing subdivision or zoning regulatione [133]. PUDs allow an ennrmons amount of flexibility in siting buildings, thus allowing proper orientation for solar utilization and minimal amounts of shading.

Though PUDs are an excellent method for securing access in developments, considerations of solar access are not generally required by PUD regulations. Such a requirement might be included in PUD regulations, especially where the applicable enabling legislation explicitly states that solar access promotes the public health, safety, or general welfare. Such modifications could either prescribe siting of buildings so as to minimize shading or merely require consideration of solar access in each PUD plan.

Another flexible technique is incentive (or bonus) zoning [134], which entitles the developer to certain specified advantages in return for providing specified features in new subdivision developments. Desired features may be awarded points in a system where the accumulation of a set number of points is required before development can 
proceed [135]. Provision of desired features can entitle the developer to special benefits, such as an increase in the allowable density of the development, or a decrease in the amount of land that must be dedicated to the public.

Incentive or bonus zoning techniques are desirable when a community wants to stop short of mandating use of solar energy or provision of solar access. A community can provide greater or lesser incentives to provide solar access, depending on the community's commitment to solar energy. 


\section{SECTION 11.0}

\section{MANDATORY USE OF SOLAR ENERGY}

There have been a number of proposals regarding more active promotion of solar technologies. The proposed legislation ranges widely in the degree of affirmative action required. At one end are proposals requiring local planning commissions to consider solar access in formulating comprehensive plans [136]. Legislation designed to improve solar access or legislation that mandates orientation of buildings for maximum solar access should be preceded by studies that consider alternative methods of meeting those goals. These studies become part of a locality's comprehensive plan that may also consider which areas of the city will be affected by new solar legislation [137].

Another proposed method for affirmatively promoting solar energy is to amend subdivision and PUD regulations so that approval of new developments would depend on whether solar energy considerations are included in the development plans [138]. Such amendments need not require that solar equipment be installed as a prerequisite to permission to develop. Consideration of solar energy may simply require energy impact statements [139] -evaluations of the energy requirements and costs of various alternative designs, possibly including both active and passive solar systems and other solar technologies. Development approval would then hinge on whether the design chosen was a reasonable one, balancing the desire to conserve energy against the cost of such conservation.

In any scheme requiring consideration of solar energy, there is a question of who has the burden of establishing the validity of conclusions reached. A locality may choose to presume that a developer's opinion of the best alternative energy system is valid. Or the locality may wish to promote solar energy by placing the burden on the developer to establish that use of solar energy is not a viable alternative [140].

The requirement of energy impact statements has been criticized as forcing every developer to repeat the same calculations needlessly. According to such criticism, if solar technology is economically viable in one case, it should also be viable in all similar cases. If there is sufficient similarity among developing parcels and a community believes that solar energy is economically feasible for those parcels, it could generally mandate the use of solar energy [141].

Mandatory solar energy use could be accomplished through building codes. Like other land-use regulations, building codes are considered to be a function of the state's police powers [142]. As such, they are subject to the same constitutional limitations as zoning ordinances. As discussed previously, the promotion of solar energy will probably be considered a legitimate state goal to be pursued through use of police powers. Indeed, if solar energy is found economically viable, mandatory use will not be a hardship.

Building code amendments to mandate use of solar energy could follow either of two basic approaches. Energy performance standards would set certain energy efficiency 
standards for various sized buildings. Performance standards allow builders to choose between passive solar features or active systems and allow flexibility to use innovative new technologies as they become available.

Such performance standards would require much expensive technical expertise to evaluate the energy used by different building designs. To avoid these administrative difficulties, a community could implement prescriptive energy standards [143]. Such standards would specify features that must be included in building designs in order to decrease the building's need for nonrenewable energy [144]. Though easier to administer than performance standards, prescriptive standards are less desirable. Their inflexibility would stifle incentives to develop and utilize technologies other than those that the building codes require. 


\section{SECTION 12.0}

\section{CONCLUSIONS}

The real issue for states and localities in the area of solar energy and land use is how. to remove land-use barriers or structure incentives for solar energy. Carefully planned and implemented land-use regulations should face no Constitutional problems. The problem involves structuring a society's land use so that solar collectors may be placed on the land and be assured of access to sunlight without causing excessive hardship to neighbors of the collector owner, creating administrative or procedural burdens, and limiting the flexibility of future development. There is no easy solution to such a problem. Each state and locality has its own needs, priorities, and existing land-use structure. It will be necessary to consider the unique situation of each area before deciding how to restructure land-use regulations that promote solar energy while creating as few problems as possible. 


\section{SEPI}




\section{SECTION 13.0}

\section{REFERENCES}

1. See Village of Euclid v. Ambler Realty Co. 272 U.S. 365 (1926); Goldblatt v. Hempstead 369 U.S. 590 (1961); A Standard State Zoning Enabling Act, U.S. Department of Commerce (1926 rev.).

2. For a discussion of height restrictions as they affect solar collectors see American Society of Planning Officials (ASPO), Land-Use Controls to Protect Solar Access: A Guidebook for Planners, Draft of report prepared for HUD, p. 70; Robbins, Proceedings of the American Bar Foundation Workshop on Solar Energy and the Law, Interim Report to the National Science Foundation (Chicago: American Bar Foundation, 1975) p. 16; Miller, "Solar Energy and Land Use in Colorado," 6 Environ. L. Rep. 539, 542 (1977); In general see, Hagman, Urban Planning and Land Development Control Law (St. Paul: West Publishing Co., 1971) \$ 58.

3. A special exception is just that, a special exception to a zoning ordinance. Generally, a list of such exceptions is written into all such zoning ordinances.

4. Fred Bair, A Model Zoning Ordinance, (Chicago: American Society of Planning Officials, 1966) p. 37 .

5. Boulder Municipal Code $\$ 37-1002(a)-(b),(1965)$.

6. An analysis of the reasons for existing height restrictions should be made to determine if the use of solar energy is sufficiently beneficial to justify a solar collector exception. For example, the Boulder ordinance (supra note 4) contains a list of several ways in which height restrictions are meant to "protect, preserve, and promote the public health, safety, and welfare." Of those listed, the following could be said to conflict with an exception for large rooftop collectors: "(3) Providing. .. that adequate light and air will be ensured to surrounding properties and that the proposed building will not interfere with views, light, and air of the community at large; ... (7) Protecting and maintaining the integrity and character of surrounding neighborhoods; (8) Protecting the aesthetic setting of the city; ... (10) Providing for property development that is compatible with the community." Balancing considerations such as (7), (8), and (10) against exceptions for solar cullectors will be discussed later. In regard to (3), one interesting consideration would be whether protruding solar collectors would impede a neighbor's access to light needed for their solar collector. If such a concern were legitimate it might not make sense to permit large solar collectors to exceed the height limit.

7. See Reid v. Architectural Board of Review, 119 Ohio App. 67, 192 N.E. 2d 74 (1963); People v. Stover, 12 N.Y. 2d 462, 191 N.E. 2d 272 (1963).

8. City of New Orleans v. Pergament 198 La. 852, 5 S. 2d 129 (1941); Opinion of the Justices to the Senate, 333 Mass. 773, 128 N.E. 2त 557 (1955); Penn Central Transportation Co. v. City of New York 438, U.S. (104 (1978); 2 R Anderson, American Law of Zoning, (2d ed. 1976) $\$ 9.69$.

9. State v. Wieland, 269 Wis. 262, 69 N.W. 2d 217 (1955); Annot., 41 ALR 3d 1397 (1972); 2 Anderson, American Law of Zoning, $\$ 9.72$. 
10. G. Hill, "Thicket of Restrictions Impeding the Use of Solar Devices," New York Times, July 4, 1978.

11. ASPO, Land-Use Controls to Protect Solar Access. (Draft). p. 70 (1979).

12. D'Aurio v. Board of Zoning Appeals, 401 N.Y. S. 2d 425 (1978).

13. Miller, Solar Energy and Land Use in Colorado. 542 (1977); in general see, Hagman, Urban Planning, $\$ 59 ; 2$ Anderson, American Law of Zoning, $\$ 9.26,9.54,9.65$.

14. Bainbridge, Planning for Solar Access: A Primer, Draft of report prepared for the California Energy Commission, March 1978.

15. Some cities may use official maps to determine where new streets will be located. If official maps are used, a subdivider may be required to build streets in accordance with the map. See in general, 4 Anderson, American Law of Zoning, $\$$ 24.02; Hagman, Urban Planning $\$ \$ 146=151$.

16. Cities that use official maps would have to amend the maps.

17. ASPO, Land-Use Controls to Protect Solar Access (draft), pp. 142-145.

18. See 2 Anderson, American Law of Zoning, $\$ 9.61$; ASPO, Land-Use Controls to Protect Solar Access (draft), pp. 79-82.

19. Hagman, Urban Planning, $\$ 60 ; 2$ Anderson, American Law of Zoning, $\$ 9.52$; ASPO, Land-Use Controls to Protect Solar Access (draft) pp. 82-89.

20. Karin Hillhouse, Solar Energy and Land Use in Colorado: Legal, Institutional, and Policy Perspectives, Interim Report of the Solar Energy Project to the National Science Foundation (Washington D.C.: Environmental Law Institute, April 1976) p. 106. PUDs will be discussed more extensively in the context of securing solar access, see text accompanying note 130 infra.

21. The Standard State Enabling Act, used in some form in most States to define the duties of the bourd of adjustment, states: "The board of adjustment shall have the following powers: 1. To hear and decide appeals where it is alleged there is error in uny order, requirement, decision, or determination made by an administration official in the enforcement of this act or of any ordinance adopted pursuant thereto ...." A Standard State Enabling Act, U.S. Department of Commerce, (1926, rev.).

22. Id. The Standard State Enabling Act in describing the powers of the board of adjustment, lists as one of its powers: ". . . To authorize upon appeal in specific cases such variance from the terms of the ordinance us will not be contrary to the public interest, where, owing to special conditions, a literal enforcement of the provisions of the ordinance will result in unnecessary hardship, and so that the spirit of the ordinance shall be observed and substantiated justice done."

23. See in general, Hagman, Urban Planning, $\$ 106$.

24. D'Aurio v. Board of Zoning Appeals, 401 N.Y. S. 20425 (1978). 
25. See, e.g., Dukeminier and Stapleton, "The Zoning Board of Adjustment: A Case Study in Misrule," 50 Ky. L.J 273 (1962); Shapiro,"The Zoning Variance Power," 29 Md. L. Rev. 1 (1969); Ellickson, Alternatives to Zoning; Covenants, Nuisance Rules, and Fines as Land-Use Controls, 40 U. Chi. L. Rev. 681 (1973).

26. In general see, 3 Anderson, American Law of Zoning $\$ \S 19.01-1932$; Hagman, Urban Planning, $\$ \$ 113-115$.

27. White, Sharon. Santa Clara, California, Community Center: Commercial Solar Demonstration, Legal Alternatives, Implications, and Financing of Solar Heating and Cooling by a Municipal Corporation, Prepared for the U.S. Energy Research and Development Administration, Sept. 1976, p. 55.

28. 5 N. Williams, American Land Planning Law, $\$ 154.01,(1974)$.

29. Even jurisdictions which reject aesthetics as a legitimate purpose of zoning regulations accept covenants which control aesthetics. See 5 Williams, American Land Planning Law, \$ 154.13; Annot., 47 ALR 3d 1232 (1973).

30. Kraye v. Old Orchard Assoc. I, Civil Action No. C209453 (Cal. Super. Ct. for L.A. Cty, February 28, 1977). The court found that the restrictive covenants conflicted with the public policy of the State of California "to encourage the use of solar energy systems," and granted declaratory relief to the property owner. During the trial, the California legislature passed a statute that voided most restrictive covenants that would hinder the use of solar energy. Though the court did not rely on the statute, its presence was of obvious importance in the Court's "public policy" decision. For a complete discussion of the case, see Wiley, "Private Land Use Controls as Barriers to Solar Development: The Need for State Legislation," 1 Solar Law Reporter, 281 (1979).

31. Some covenants have provisions which allow modification by less than unanimity.

32. Hill, supra note 10 .

33. Smith v. North 244 Cal. App. 2d 245, 248, 53 Cal. Rptr. 94, 95 (1966).

34. Hagman, Urban Planning, $\$ 168$.

35. 5 Williams, American Land Planning Law, $\$ 154.10$.

36. 87 N.Y. $311(1881)$.

37. Id.

38. 5 Williams, American Land Planning Law, $\$ 154.10$.

39. See text accompanying note 30 supra.

40. Wiley, "Private Land Use as Barriers to Solar Development," 1 Solar Law Reporter, 281 (1979).

41. Id. 
42. Cal. Civ. Code $\$ 714$ (West Supp. 1979).

43. Note, "Legal and Policy Conflicts Between Deed Covenants and Subsequently Enacted Zoning Ordinances," 24 Vand. L. Rev. 1031, 1042 (1971).

44. For a discussion of nuisance as a barrier to solar energy usage see Zillman \& Deeny, "Legal Aspects of Solar Energy Development," 1976 Ariz. St. L. Rev. 25,39.

45. L. Coit, Wind Energy: Legal Issues and Institutional Barriers, SERI (1979).

46. Prosser, The Law of Torts, 572 (4th ed. 1971).

47. Id. at 577 .

48. "Wind Energy: Legal Issues and Legal Barriers" 31 S.W. Law J. 1053.

49. See, e.g., G. Hayes, Solar Access Law: Protecting Access to Sunlight fur Solar Energy Systems, Environmental Law Institute (1979); Legal Barriers to Solar Heating and Cooling of Buildings, Environmental Law Institute, prepared for U.S. Dept. of Energy, 1976; Moskowitz, "Legal Access to Light: The Solar Energy Imperative," 9 Nat. Res. Law 177 (1976); Bersohn, "Securing Sular Energy Rights: Easements, Nuisance, or Zoning?" 3 Colum. Jrnl. Envirn. L. 112 (1976); Eisenstadt \& Utton, "Solar Rights and Their Effects on Solar Heating and Cooling" 16 Nat. Res. J. 363 (1976); Zillman, supra note 44; Thomes, Miller, \& Robbins, "Overcoming Legal Uncertainties About Use of Solar Energy Systems," American Bar Foundation, 1978; Reitze, "Solar Rights Zoning Guarantee: Seeking New Law in Old. Concepts," 1976 Wash. U.L.Q. 375; White, "The Allocation of Sunlight: Solar Rights and the Prior Appropriation Doctrine," 47 U. Colo. L. Rev. 421 (1976); Becker, "Common Law Sun Rights: An Obstacle to Solar Heating and Cooling," $3 \mathrm{~J}$. Contemp. Law 19 (1976); Miller, "Let the Sunshine In: A Comparison of Japanese and American Solar Rights," I Harv. Env. L. Rev. 578 (1976); Comment, "Solar Rights: Guaranteeing a Place in the Sun," 57 Ore. L. Rev. 94 (1978).

50. For legal literature see note 49; for government studiës seè: Hlllhouse, supru, noto 20, Protecting Solar Acress, Repnrt of the Governors Special Study Committee on Solar Rights, Wisconsin Office of State Planning and Energy, April 1978; Block, Solar Access Study, Florida Solar Energy Center, April 1978; A Forum on Solar Access, Proceedings of a Forum on Solar Access Held by the New York State Legislative Commission on Energy Systems, Available from National Solar Heating and Cooling Information Center, July 1977; For land use planning literature see, ASPO, Land-Use Controls to Protect Solar Access (draft) supra note 2; Bainbridge, Planning for Solar Access, supra note 14 .

51. Harris, Is the Right to Light a California Necessity?, A Prepared statement submitted before the California State Assembly Committee in the Judiciary, Rand Corporation, Dec. 1975, p. V.

52. In the northern hemisphere the sun always appears to the south, therefore a tall structure or tree on property to the south is capable of completely obstructing direct sunlight needed for efficient operation of a solar collector. Therefore, the right to solar energy is really a right to restrict development or growth of vegetation on property to the south. For greater detail on how to calculate how much shading a particular structure causes, see ASPO, Land Use Controls to Protect Solar Access; Bainbridge supra note 14; Eisenstadt supra note 49. 
53. For thorough discussions of common law rights to light, see Bersohn, supra note 49; Becker, supra note 49; Moskowitz, supra note 49.

54. Right to Light Act of 1959, 7 and 8 Eliz 2 c. $56 \$ \$ 2,3$. The prescriptive period for a right to light in England today is 27 years.

55. See, e.g., Hunt Land Holding Co. v. Schramm 121 So. 2d 697 (Fla., 1960); In general see, $3 \mathrm{R}$ Powell, Real Property $\$ 413$ (1968).

56. Bersohn, supra note 49; also see Taliaferro v. Salyer, 162 Cal. App. 2d 685, 328 P.2d 799 (1958), holding that an easement for light and air may only be created by express grant.

57. See Zillman, supra note 44 , p. 39 .

58. Id. However see Bersohn, supra note 49, ("The prospects for achieving insolation rights under nuisance doctrine are not good at present, but ought to improve when applied solar technology becomes commonplace" p. 134).

59. In general see, 3 Powell, Real Property, $\$ 405$; also see United States v. Causby 328 U.S. 256, 264 (1964)" [nt is obvious that if the landowner is to have full enjoyment of the land, he must have exclusive control of the immediate reaches of the enveloping atmosphere ... The landowners own at least as much of the space above the ground as he can occupy or use in connection with the land." Also see Wright, The Law of Airspace, pp. 259-60 (1968).

60. Restatement of Property $\$ 450$ (1936).

61. See, e.g., Colo. Rev. Stat. $\$ \S 38-32.5-101$ to 102 (Supp. 1975); N.D. Cent. Code $\S$ 47-05-01.1, .2 (Allen Smith Supp. 1977); Ill. Ann. Stat. ch. 96-1/2, \$ 7303 (f) (West Supp. 1978); Kan. Stat. $\$ \S 58-3801,3802$ (Supp. 1977); 1978 Minn. Laws, ch. 786, $\$$ 500.30 ; also see the model solar easement statute in Thomas, Miller, and Robbins supra note 49 , pp. 44-46.

62. See Protecting Solar Access, supra note 50, pp. 10-11.

63. See, e.g., Cal. Civ. Code $\$ 801$ (8) (West 1954).

64. In general, it should be easier to provide secure access in new developments through legislation than it would be in existing neighborhoods.

65. Some states require that property taken by eminent domain must be used by the public. However, the majority of states allow use of eminent domain whenever the taking of private property will benefit the general welfare in a direct sense. See Berman v. Parker 348 U.S. 26 (1954); 2A Nichols, Eminent Domain, $\$ 7.2$ (3d. ed, 1976).

66. For a discussion of assessing costs against those who benefit by use of eminent domain see: Dunham, "A Legal and Economic Basis for City Planning," 58 Colum. L. Rev. 650 (1958), pp. 663-69.

67. It is also possible to allow the cost of easements to be considered part of the cost of a solar energy system for the purpose of solar tax credits. 
68. See notes 28-29 and accompanying text, supra.

69. The following discussion will be limited to providing access to sunlight. Proposed legislation to secure access has not included access to wind for wind generators. This could be because wind generator technology is not as close to widespread commercialization as are technologies using sunlight. Or, it could be because it would be much more difficult to secure access to wind, since surrounding land use would have to restricted in all directions from the wind generators.

70. White, supra note 49 , pp. $422-426$.

71. Even when localities have a general delegation of police powers, they still need specific delegations to control land use through zoning. See: 1 Anderson, American Law of Zoning $\$ \$ 2.19-2.29$.

72. A Standard State Enabling Act, U.S. Department of Commerce, (1926, rev.).

73. Minnesota 1978 Session Laws, ch. $786 \S 14$, amending Minn. Stat. $\$ 462,357$ (1) (1976).

74. Also see Ore. Rev. Stat. 215.110 (g) (1977 Supp.); Miller, Thompson, and Robbins, supra, note 49 , pp. 49-5i.

75. For an example of state enabling legislation that allows localities to allocate solar rights, see, N.M. Stat. Ann. \$ 70-8-1 (1978 Supp.).

76. Village of Euclid v. Ambler Realty Co. 272 U.S. 365 (1926); Village of Belle Terre v. Boraas, 416 U.S. 1 (1974).

77. See, e.g., Reitze, supra note 49 , p. 393 , ("there would be no difficulty . . . in justifying the protection of solar cullecturs us devices to enhance health and welfare by reducing pollution and conserving resnuress, purposes well within the traditional justification for zoning regulations").

78. "An attempt to define its [police powers] reach or trace its outer limits is fruitless, for each case must rest on its own facts. The definition is essentially the product of legislative determinations addressed to the purposes of government, purposes neither abstractly nor historically capable of complete definition. Subject to specific constitutional limitations, when the legislature has spoken, the public interest has been declared in terms well-nigh conclusive." Berman v. Parker, 348 U.S. 26 (1954).

79. For a discussion of equal protection concerns in solar rights legislation see White, supra note 27, pp. 14-15.

80. Id. p. 14; also see Nector v. City of Cambridge, 277 U.S. 183 (1928).

81. Village of Belle Terre v. Boraas, 416 U.S. 1 (1974). 
82. A case discussing the takings issue is Pennsylvania Coal Co. v. Mahon, 60 U.S. 393 (1922); see also Dunham, "A Legal and Economic Basis for City Planning," 58 Colum. L. Rev. 650 (1958); Sax, "Takings, Private Property and Public Rights," 81 Yale L.J. 149 (1971); Michelman, "Property, Utility and Fairness: Comments on the Ethical Foundations of 'Just Compensation' Law," 80 Harv. L. Rev. 1165 (1968).

83. See, e.g., Goldblatt v. Town of Hempstead, 369 U.S. 590 (1962).

84. See discussion supra at notes 57 et seq.

85. See Michelman, supra note 81 .

86. Id. at 1171-72.

87. See, e.g., Village of Euclid v. Ambler Realty Co., 272 U.S. 365 (1926); for a recent case discussing the issue see, Penn Central Transportation Co. v. City of New York, 438 U.S. 104 (1978).

88. See, e.g., Pennsylvania Coal Co. v. Mahon, 260 U.S. 393, 415 (1922).

89. Some states would require inclusion in comprehensive plans. See, e.g., Cal. Govt. Code $\$ 65302$ (Supp. 1973).

90. For an example of a comprehensive plan that considers solar access, see, Albuquerque/Bernalillo County Comprehensive Plan; Policies Plan, Dec. 1974, Discussed in Eisenstadt, supra note 49.

91. See Penn Central Transportation Co. v. City of New York, 438 U.S. 104 (1978).

92. For a discussion of how to integrate solar access policies into comprehensive plans see, ASPO, Land-Use Controls to Secure Solar Access, pp. 48-51; also see, Thomas, Miller, and Robbins, supra note 49, pp. 61-62; Hillhouse, supra note 20, pp. 100-105.

93. ASPO, Land-Use Controls to Secure Solar Access, pp. 45-47.

94. See Miller, "Solar Energy and Land Use in Colorado," 6 Environ. L. Rep. 539, 542.

95. See Miller v. Schoene, 276 U.S. 272 (1928) (trees had to be cut down because they harbored disease fatal to nearby apple trees. Though the state paid for the cost of removal, they did not have to compensate for the decrease in value of the property caused by the removal of the trees.)

96. See, e.g., White, supra note 27, pp. 52-58; Eisenstadt, Long, Utton, A Proposed Solar Zoning Ordinance, University of New Mexico Energy Institute Report No. 76113, Nov. 1977; In general, see, ASPO, Land-Use Controls to Protect Solar Access (draft) pp. 74-134.

97. ASPO, Land-Use Controls to Protect Solar Access (draft) pp. 89-103.

98. Id. p. 91 .

99. Id. pp. 91-94. 
100. The structure cannot be moved to the north as that would decrease the solar access of the property to the north.

101. ASPO, Land-Use Controls to Protect Solar Access (draft), p. 92.

102. Eisenstadt, Long, \& Utton, supra note 96; Los Alamos County Zoning Ordinance No. 173 , as amended, effective Jan. $31,1978$.

103. Some states now allow an amoritization period for preexisting nonconforming uses rather than a blanket exception. See Graham, "Legislative Techniques for the Amoritization of the Nonconforming Use: A Suggested Formula," 12 Wayne L. Rev. 435 (1966).

104. See Miller v. Schoene, supra note 91 ; also see Eisenstadt, Long, Utton supra note 96 at 11, (proposed zoning ordinance would require owner of solar collector to pay for tree removal); Courts that accept the argiment thut restrictions on land use need no compensution only when they seek to avoid a nuisance-like activity would probably require compensation if trees must be removed. It is difficult to conceive of trees as nuisance-like, indeed, they would usually be thought of as beneficial to the public.

105. Eisenstadt, Long, Utton, supra note 96 , pp. 7-9.

106. ASPO, Land-Use Controls to Protect Solar Access (draft) pp. 94-95.

107. Spot zoning is the singling out of a parcel and treating it differently from similarly situated parcels. Usually a charge of spot zoning is overcome by proof that the zoning is consistent with a comprehensive plan. See Penn. Central Transportation Co. v. City of New York, 438 U.S. 104 (1978) in which the court rejected an argument that a zoning ordinance that restricted development of the Grand Central Station for historic preservation purposes was an instance of spot zoning. The Court said, "But, contrary tn appellant's suggostiono, landmark laws ure liul like discriminating, or 'reverse spot' zoning: that is, a land use dccision which arbitrarily singles out a particular parcel for different, less favorable treatment than the neighboring ones . . . . In rontrast to dicoriminating zoning, whicli is tlie antithesis of land use control as part of some comprehensive plan, the New York City law embodies a comprehensive plan to preserve structures of historic or aesthetic interest wherever they might be found in the city ...;" See in general, Haar, In Accordance with a Comprehensive Plan, 68 Harv. L. Rev. 1154 (1955).

108. Transferable solar rights have been suggested by: Harris, supra note 48; Eisenstadt supra note 46; Comment, "Solar Rights: Guaranteeing a Place in the Sun," supra note 46 .

109. N.M. Stat. Ann. $\$ 70-80-1$ (1978 Supp.).

110. See Comment, "Solar Rights: Guaranteeing a Place in the Sun," supra note 49, pp. 122-124.

111. See, e.g., Harris, supra note 51; Reitze, supra note 49, pp. 400-402; Often there is not a clear demarcation between zoning for solar access and allocating solar rights. In particular, a zoning ordinance for solar access combined with legislation that disallows shading collectors installed in reliance on a zoning ordinance has an effect equivalent to an allocated solar right. 
112. See text accompanying note 56 , supra.

113. See text accompanying notes $85-92$, supra.

114. White, supra note 49 .

115. See, e.g., Hillhouse, supra note 20, pp. 118-120; Legal Barriers to Solar Heating and Cooling of Buildings, supra note 49, pp. 26-29; Protecting Solar Access, supra note 50, pp. 18-20.

116. White, supra note 49 , p. 437 .

117. Protecting Solar Access, supra note 50, pp. 18-20.

118. Legal Barriers to Solar Heating and Cooling of Buildings, supra note 49, pp. 26-29.

119. See text accompanying notes 104-106, supra.

120. White, supra note 49 , pp. $439-440$.

121. Id. p. 440 .

122. Id. p. 436 .

123. See notes $82-87$ and accompanying text, supra.

124. See the discussion eminent domain in notes 65-67 and accompanying text, supra.

125. See note 110 supra.

126. In 1978 California passed a law that declared that the shading of solar collectors by vegetation is a public nuisance. California's Solar Shade Control Act is in Cal. Public Resource Code Div. 15, Ch. 12, \$25980 et seg. The Act prohibits trees or shrubs from shading more than $10 \%$ of the surface area of a solar collector during certain hours of the day. Trees that cast a shadow on the collector when it is installed arc exempted. The hill puts some limitation on where a collector may be placed on the property.

127. For a discussion of the drawbacks to use of public nuisance see Legal Barriers to Solar Heating and Cooling of Buildings, supra note 49 , pp. 8-9; it is possible to legislatively allow declaratory judgments on whether the shading of a particular location will be a nuisance, even before the collector is installed. Such an action normully would not be allowed since there is no alleged nuisance until the collector is actually shaded, and the reasonableness of a property use cannot be evaluated in the abstract. If declaratory judgments were allowed, the effect would be to create a system of allocated solar rights, with the courts acting as the administrative agency to which property owners apply for their rights.

128. Costonis, Proceedings, supra note 2, pp. 19-21.

129. See, Costonis, "The Chicago Plan: Incentive Zoning and the Preservation of Urban Landmarks," 85 Harv. L. Rev. 574 (1972); Schnidman, "Transferable Develupilitilt Rights: An Idea in Search of Implementation," 11 Land and Water Rev. 339 (1975). 
130. For a description of how the New York historical preservation zoning works, see: Penn Central Transportation Co. v. City of New York, 438 U.S. 104 (1978).

131. ASPO, Land-Use Controls to Protect Solar Access, (draft), p. 85.

132. In 1978, Minnesota amended their zoning and subdivision enabling statutes to make it clear that localities could regulate land to provide access for solar collectors. For example, the subdivision enabling statute, Minn. Stat. $\$ 462.358$ (1976), was amended to include the following: "A municipality may, for purposes of protecting and assuring access to direct sunlight for solar energy systems, prohibit or restrict or control development through subdivision regulations. The regulations may call for subdivision development plans containing restrictive covenants, height restrictions, side yard and setback requirements, or other permissible forms of land use controls." Minnesota 1978 Session laws, ch. 786, $\$ 16$.

133. See Hillhouse, supra note 20, pp. 105-108; ASPO, "I,and IIse C.ontrols to Protoot Solar Access," (draft), pp. 117-124.

134. See Bersohn, supra note 60, pp. 141-150, for a discussion of New York City's Zoning for Housing Quality (ZHQ), a system of bonus zoning that is amenable to providing solar access. Also see ASPO, Land-Use Controls to Protect Solar Access, (draft), pp. 126-130; For a case upholding the validity of incentive or bonus zoning system, see: Golden v. Planning Board of Town of Ramapo, 30 N.Y. 2d 359, 334 N.Y.S. 2d 138, 285 N.E. 2d 291, app. dismissed 409 U.S. 1003 (1972).

135. See, e.g., Hillhouse, supra note 20, pp. 104-105, which discusses incentive zoning in Boulder, Colo: Applicants for building permits are judged according to how many points they have eurned on a 100-point merit system. Including a solar collector, either active or passive, other solar technologies, or energy conserving architecture can be worth up to ten points. See, Rev. Code of the City of Boulder, $\$ 37-1305$ (1.977 supp.).

136. See Hillhouse, supra note 22, pp. 100-105; Thomas, Miller, Robbins, supra note 60, pp. 51-52.

137. See notes 88-92, and accompanying text supra.

138. See Ayers v. City Council of the City of Los Angeles, 207 P. 2d 1 ("It is the petitioner who is seeking to acquire the advantages of lot subdivision and upon him rests the duty of compliance with reasonable conditions for design, dedicating improvement and restrictive use of land so as to conform to the safety and general welfare of the lot owners in the subdivision and the public." P. 7); also see, Heyman, and Gilhod, "The Constitutionality of Imposing Increased Communily Costs on New Suburban Residents Through Subdivision Exactions" 73 Yale L.J. 1119 (1964).

139. See "Legal Barriers to Solar Heating and Cooling of Buildings," supra note 49, pp. 36-37; See also: K. Perlman, "State Environmental Policy Acts: Local Decision Making and Land-Use Planning," 43 J. Amer. Inst. of Planners 42 (1977). 
140. For instance, the New Jersey Department of Energy has proposed that all new developments of six homes or more must take full advantage of passive and active solar technologies where feasible. The Department also suggests that, "The burden will be on the developer to demonstrate to the Department why passive and/or active solar concepts are not applicable to the project." Solar Energy in New Jersey: Problems, Potential, and Policies Preliminary Policy Statement, New Jersey Department of Energy, April 1978, p. 16.

141. See Thomas, Miller, Robbins, supra note 49, p. 50, for a proposed "mandatory solarenergy-use districts" statute.

142. See Hagman, "Urban Planning," p. 280.

143. Florida has a type of prescriptive standard. Florida requires that the plumbing in all new houses be designed so that retrofit of solar hot water heaters will be easy. See Fla. Stat, Ann. $\$ 553.87$.

144. It is possible to specify prescriptive standards, but allow flexibility to design buildings in other ways so long as the different designs match the performance of the prescribed standards. 


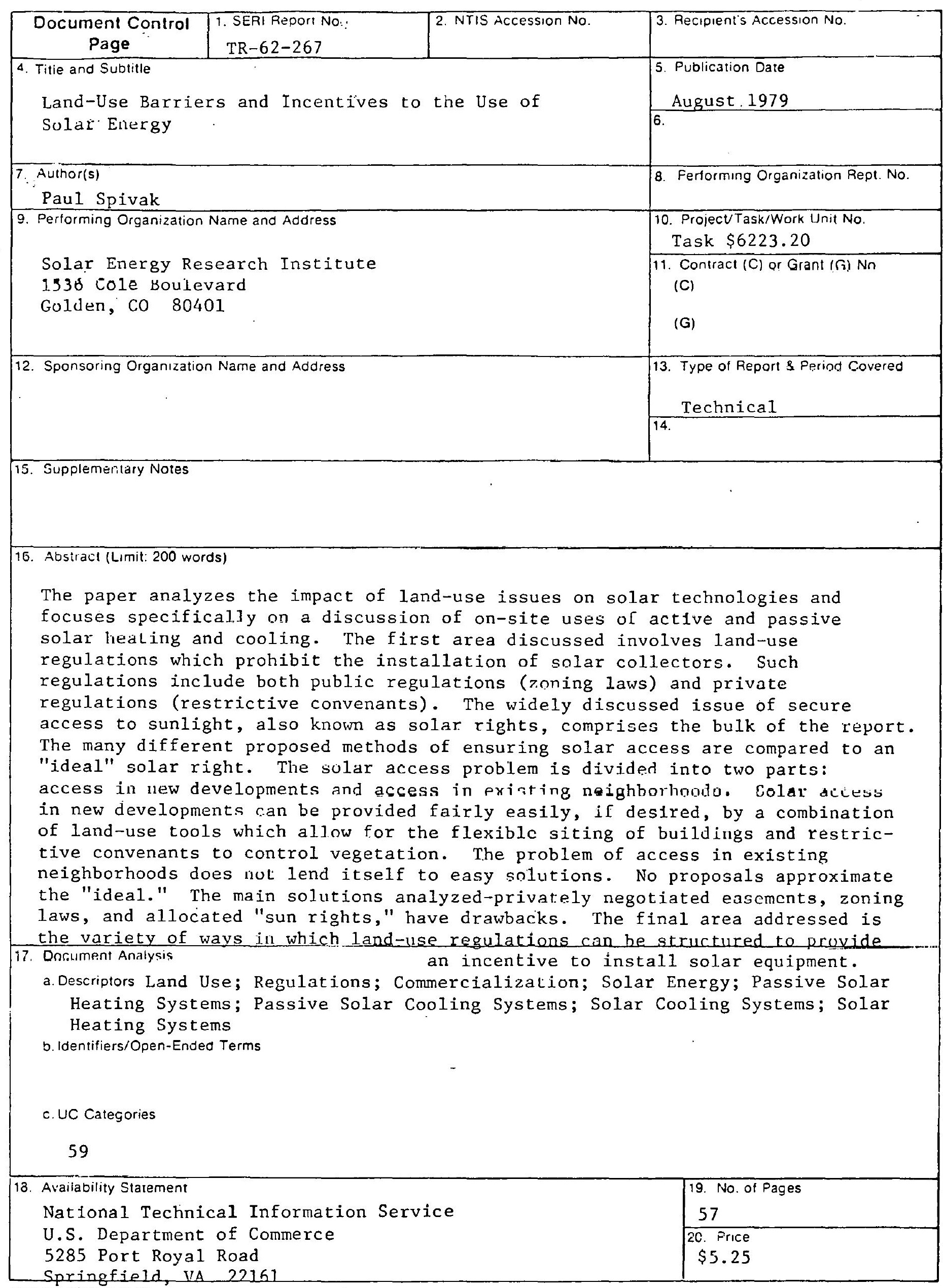

